J.D. Despain, B.W. Tobin, and G.M. Stock - Geomorphology and paleohydrology of Hurricane Crawl Cave, Sequoia National Park, California. Journal of Cave and Karst Studies, v. 78, no. 2, p. 72-84. DOI: 10.4311/2013ES0114

\title{
GEOMORPHOLOGY AND PALEOHYDROLOGY OF HURRICANE CRAWL CAVE, SEQUOIA NATIONAL PARK, CALIFORNIA
}

\author{
Joel D. Despain ${ }^{*}$, Benjamin W. Tobin², and Greg M. Stock ${ }^{3}$
}

\begin{abstract}
Hurricane Crawl Cave in Sequoia and Kings Canyon National Parks, California, contains adjacent but varied passage morphologies including network and anastomotic mazes, large rooms, narrow canyons, prolific speleothems, and multiple levels that collectively are difficult to explain. We investigated the cave through cartography, geochronology, dye traces, modern discharge measurements, and paleodischarge estimates from scallop and cobble measurements. The cave has strong structural control along vertically oriented beds and subparallel fractures. ${ }^{26} \mathrm{Al} /{ }^{10} \mathrm{Be}$ burial dating of coarse clastic sediment suggests a minimum cave age of $1.4 \mathrm{Ma}$, and a time-averaged in-cave incision rate of $0.02 \mathrm{~mm} \mathrm{y}^{-1}$. Dye traces proved that an obvious surface stream is the source of the primary stream in the cave, but that other small streams rise from diffuse flow. Modern discharge measurements range from 0.042 to $0.002 \mathrm{~m}^{3} \mathrm{~s}^{-1}$. Paleodischarge and flow velocity values determined from scallops and cobbles vary more in relation to passage morphology than to passage elevation, a proxy for time. Paleodischarges were orders of magnitude larger than modern discharge. We attribute varied morphology and location of mazes to temporally and spatially variable sediment flux and stream discharges. Higher sediment loads and stream discharges promote the development of passages with anastomotic maze morphology. The morphology of Hurricane Crawl Cave differs from that Crystal Cave, which is in the same basin, primarily due to a comparatively lower sediment load.
\end{abstract}

\section{INTRODUCTION}

Caves and karst of the Kaweah River basin in Sequoia and Kings Canyon National Parks, California (Fig. 1), have proven ideal locations to study the hydrologic behavior of mountain karst aquifers, the geomorphology of caves and karst in the region, and how these features relate to the overall geomorphic evolution of the Sierra Nevada. Hydrologic research has identified the causes of unique aquifer behavior at Big Spring and Lilburn Cave (Abu-Jaber et al., 2001; Urzendowski, 1993), the relationships between surface and groundwater systems (Tinsley, et al., 1981; Tobin and Schwartz, 2012), and the importance of karst aquifers to river flow (Despain and Stock, 2005; Tobin and Schwartz., Submitted). Geomorphic histories of caves in the basin have provided insight into cave geomorphology (Despain and Stock, 2005; Despain et al., in review), geochronology (Stock et al., 2005b), and the history of regional mountain uplift and canyon incision (Stock et al., 2004; Stock et al, 2005a). These previous works have primarily focused on the two longest cave systems in the river basin, Lilburn Cave and Crystal Cave, with some additional work on large springs not associated with extensive cave passages. To assess the karst hydrologic and geomorphic history of the Kaweah River basin further, this research aims to describe the hydrologic and geomorphologic history that led to the variety of passage forms in the third-longest cave system in the basin, Hurricane Crawl Cave (HCC). HCC developed in very similar hydrologic and geologic conditions to Crystal
Cave, the second longest in the basin, yet they have very different morphologies. This research seeks to explain why.

\section{Hurricane Crawl Cave}

HCC contains $3132 \mathrm{~m}$ of surveyed passage with a vertical extent of $70.5 \mathrm{~m}$ in a canyon in the watershed of the North Fork of the Kaweah River, with the lower entrance and the cave resurgence at an elevation of $1220 \mathrm{~m}$ amsl. The cave was discovered by national park staff and cavers from the San Francisco Bay area in 1986 (Despain, 1999; Stock 1999). The cave has varied morphologies that imply a varied and complex history. Adjacent passage types in Hurricane include both anastomotic and network mazes (Palmer, 1975; 1991), rooms $35 \mathrm{~m}$ across, canyons $20 \mathrm{~m}$ deep and $1 \mathrm{~m}$ wide, and multiple levels (Fig. 2 and Fig. 3).

The Sierra Nevada has a Mediterranean climate with long dry summers and wet winters with rain at lower elevations and snow generally above $1500 \mathrm{~m}$. Most of the basin for HCC lies within the snow zone, while the cave itself is at an elevation of $1220 \mathrm{~m}$ to $1300 \mathrm{~m}$. Surface and cave streams in the Sierra Nevada experience periods of high discharge due to runoff from spring snowmelt and from

\footnotetext{
* Corresponding author: joeldespaincaves@gmail.com

${ }^{1}$ Joel D. Despain, 27171 State Highway 299 East, Bella Vista, CA 96008, USA.

${ }^{2}$ Benjamin W. Tobin, National Park Service, Grand Canyon National Park, Grand Canyon, AZ 86023, USA.

${ }^{3}$ Greg M. Stock, National Park Service, Yosemite National Park, El Portal, CA 95318, USA.
} 


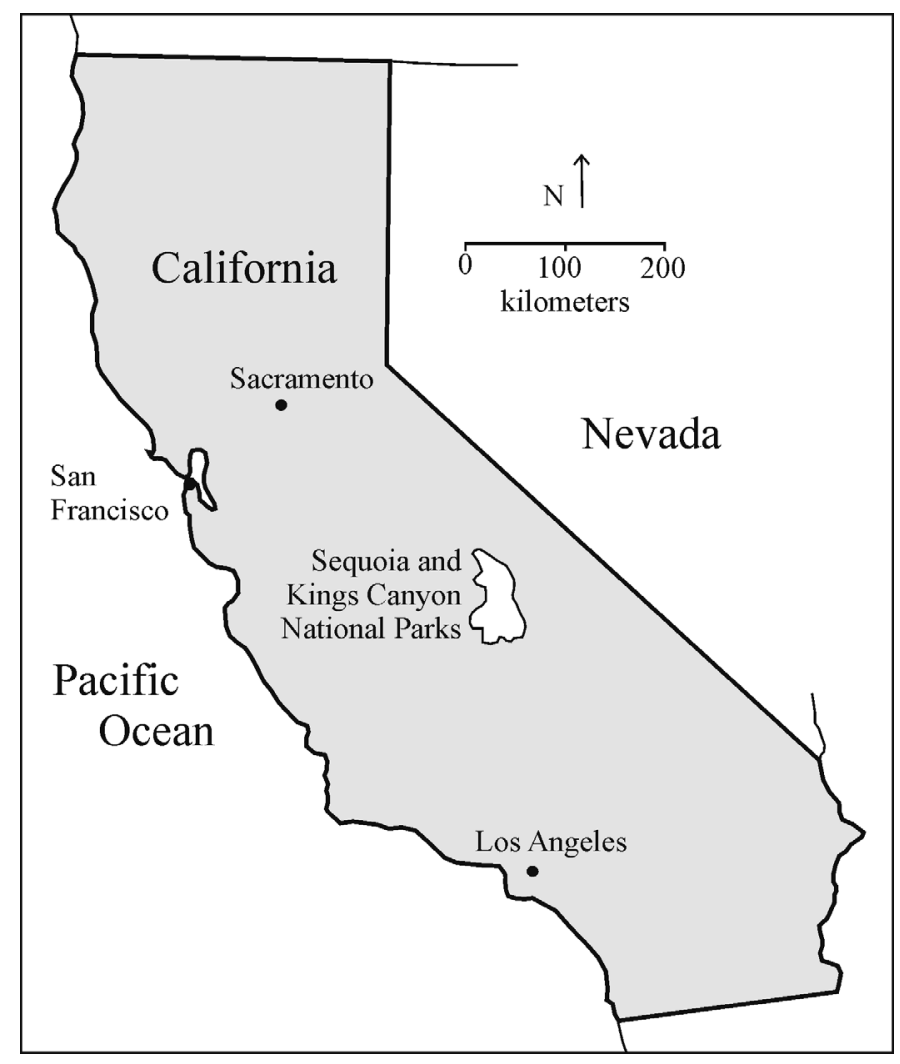

Figure 1. Location map of Sequoia and Kings Canyon National Parks, California, USA.

infrequent rain-on-snow events during warm winter storms. This causes flooding within caves of the region (Tinsley, et al., 1981; Despain and Stock, 2005). Floods overwhelm existing stream conduits, promoting the development of network, and much more frequently, anastomotic mazes within caves (Palmer, 1975; 1991).

HCC developed in vertically bedded Mesozoic marble of the Sequoia Pendant of metamorphosed marine rocks assigned to a Triassic to Jurassic timeframe and as a component of the Kings Sequence and Kings Terrane (Bateman and Clark, 1974; Saleeby et al, 1978; Nokleberg, 1983). Multiple marble bodies within the metamorphic pendant are bounded by quartzite schist (Sisson and Moore, 1994) seen in prominent outcrops on the surface and in many caves. These contacts' conformal bedding are within 10 degrees of vertical (Despain and Stock, 2005). Many similar pendants occur in the Sierra Nevada and are generally surrounded by larger granitic plutons. The Sequoia Pendant is approximately $4 \mathrm{~km}$ wide and $18 \mathrm{~km}$ long and lies parallel to the crest of the Sierra Nevada, trending north-northwest to south-southeast. HCC formed in the central of three parallel marble lenses. This body of marble is 100 to $300 \mathrm{~m}$ wide and $3 \mathrm{~km}$ long (Sisson and Moore, 1994) (Fig. 4).

Two entrances allow access to the cave through breakdown collapses near the upstream and downstream termini; these collapses likely relate to stress-relief fracturing along

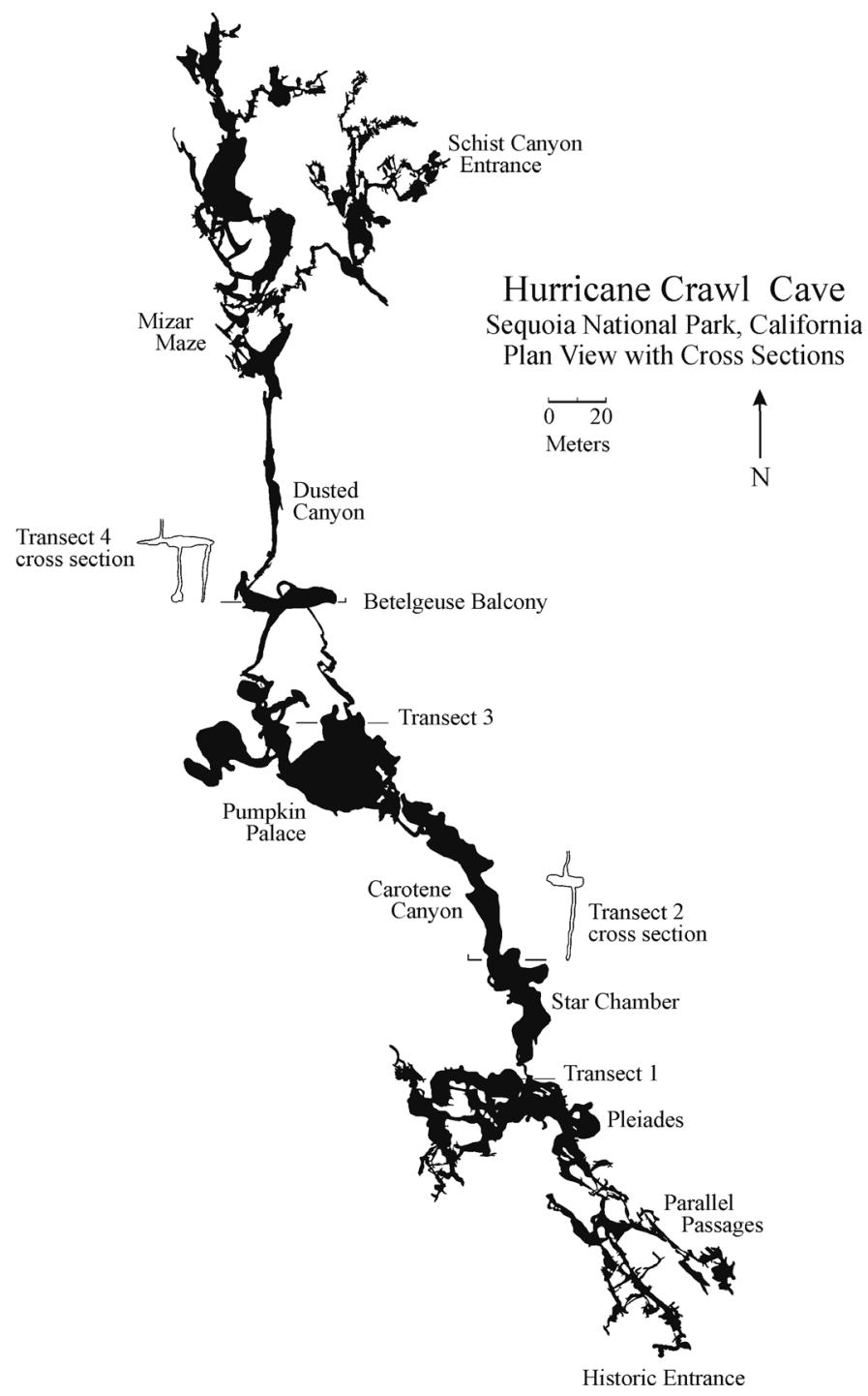

Figure 2. Plan view map of Hurricane Crawl Cave showing locations of vertical transects and locations referenced in the text.

the canyon walls (e.g., Sasowsky and White, 1994). The cave has three perennial streams, although two have very low discharge, with base flows of less than $0.001 \mathrm{~m}^{3} \mathrm{~s}^{-1}$. Much of the cave's lowest level is composed of two narrow, tall canyon passages with streams (Fig. 5), although mazes are found at the upstream and downstream margins. A large room, Pumpkin Palace, is in the central portion of the cave (Fig. 6).

The cave stream emerges as a series of small springs on the banks of the local base-level stream, a major tributary to the North Fork of the Kaweah River. Inside the cave are many small knickpoint waterfalls up to $2 \mathrm{~m}$ in height, particularly near the downstream cave terminus and the spring. The surface base-level stream to which the cave drains lies in a steep canyon with many knickpoints and waterfalls 5 to $30 \mathrm{~m}$ tall. The headward migration of knickpoints past the cave very likely drove vadose cave stream 


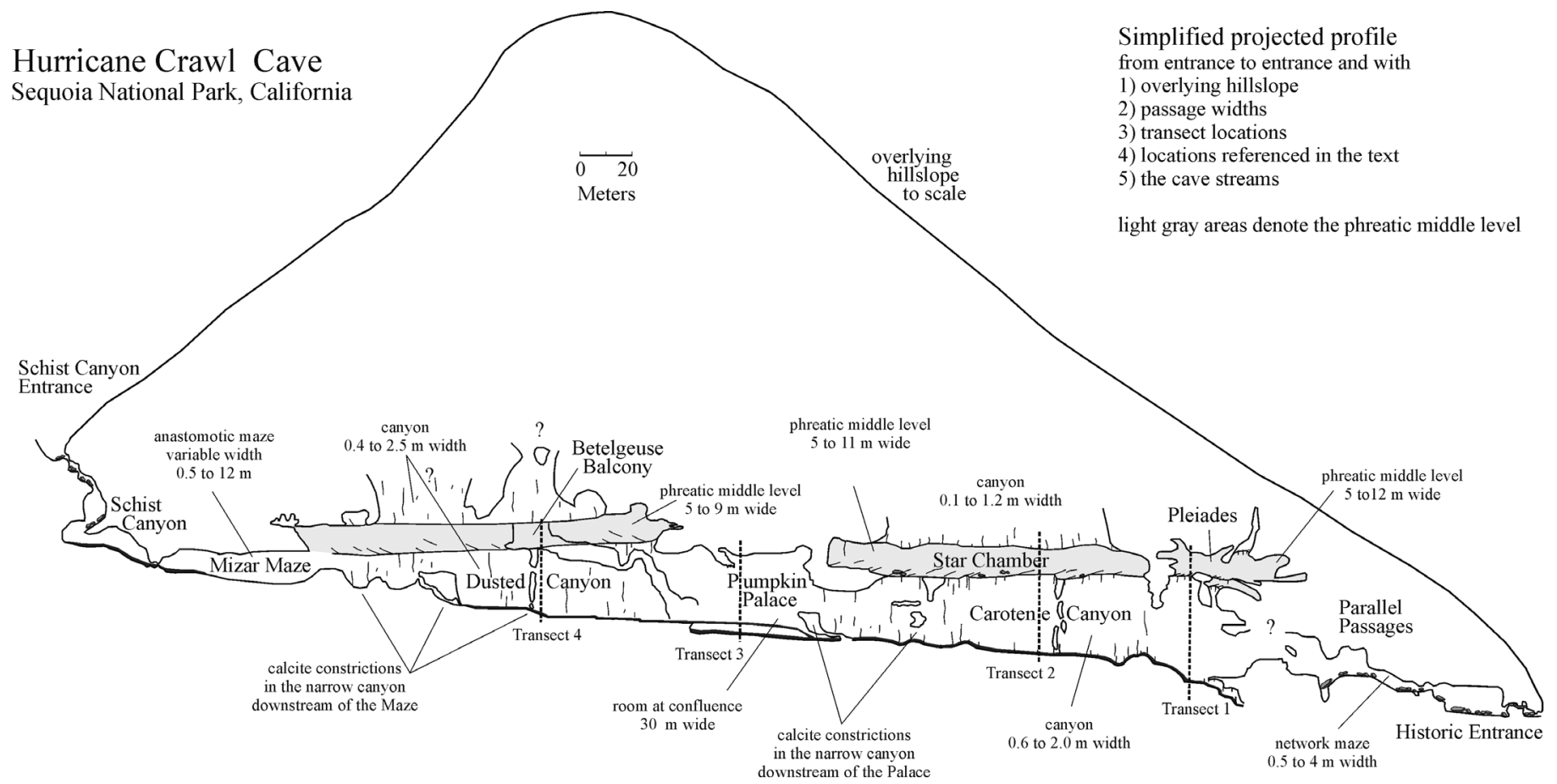

Figure 3. Profile view map of Hurricane Crawl Cave showing transects, locations referenced in the text, passage widths and types, the cave streams, and the overlying hillslope.

incision and the development of vadose canyons. This has been suggested for Crystal Cave (Despain and Stock, 2005), also in the North Fork of the Kaweah watershed.

Above the lowest canyons, the cave has two other welldefined levels. The first and primary one is a broad passage

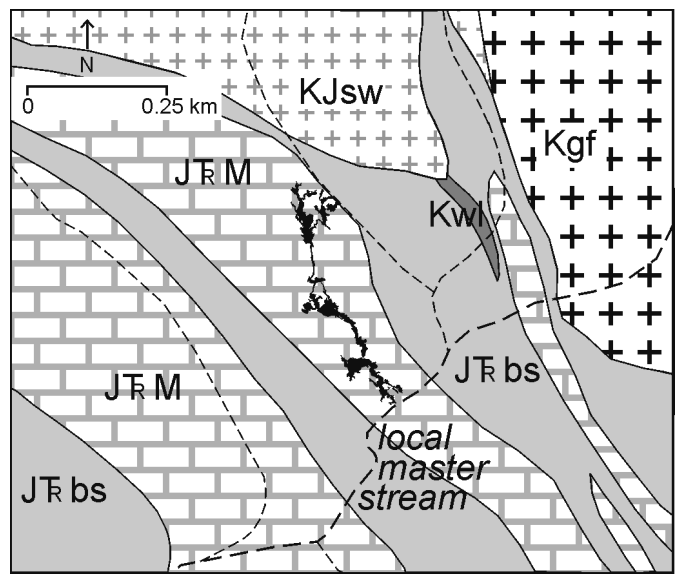

Figure 4. Geologic map with local surface streams (dashed lines) and the Hurricane Crawl Cave footprint in black (adapted from Sisson and Moore, 1994). JTR m marble, Jurassic and/or Triassic; JTR bs biotite-feldspar-quartz schist, Jurassic and/or Triassic; KJsw granite of Skagway Grove, Cretaceous or Jurassic; Kgf Giant Forest Granodiorite, Cretaceous; Kwl granite of Weaver Lake, Cretaceous. The name of the stream is omitted to protect the location of the cave.
6 to $14 \mathrm{~m}$ wide. It is accessible at four locations where vertical passages are not filled by speleothems deposits. Prominent passages at this level include the Star Chamber and the Pleiades. Above this level is another, higher canyon that can be accessed in only two locations due to its vertical orientation and prolific delicate speleothems found between narrow walls. From these two locations the canyon can be entered for a few tens of meters.

Passages at all levels end in collapse, secondary calcite infill, or both where conduits approach the surface. These locations often have roots or organic soils and may act as entrances for small animals and airflow. Specific areas of collapse near the surface occur in the Parallel Passages, Pleiades, Mizar Maze, and Schist Canyon.

Granitic sediments derived from upstream watersheds are very common in sierran caves and vary from cobbles and gravels to silts and clays (Tinsley, et al., 1981; Stock et al., 2005b; Despain and Stock, 2005). Passages are sometimes completely filled by sediment or show evidence of being filled in the past, such as sediments in bedrock wall and ceiling notches. This implies a return to phreatic conditions and possible paragenetic cave development (Farrant and Smart, 2011) in Sierra Nevada caves. Sediment distribution within HCC varies because of the cave's varied morphology of rooms separated by narrow canyons. Steep-walled canyon passages have almost no storage capacity for fluvial sediments, while cave rooms have floors of sediments or speleothems that have been deposited on top of sediments. In addition to standard carbonic-acid dissolution in the development of cave 


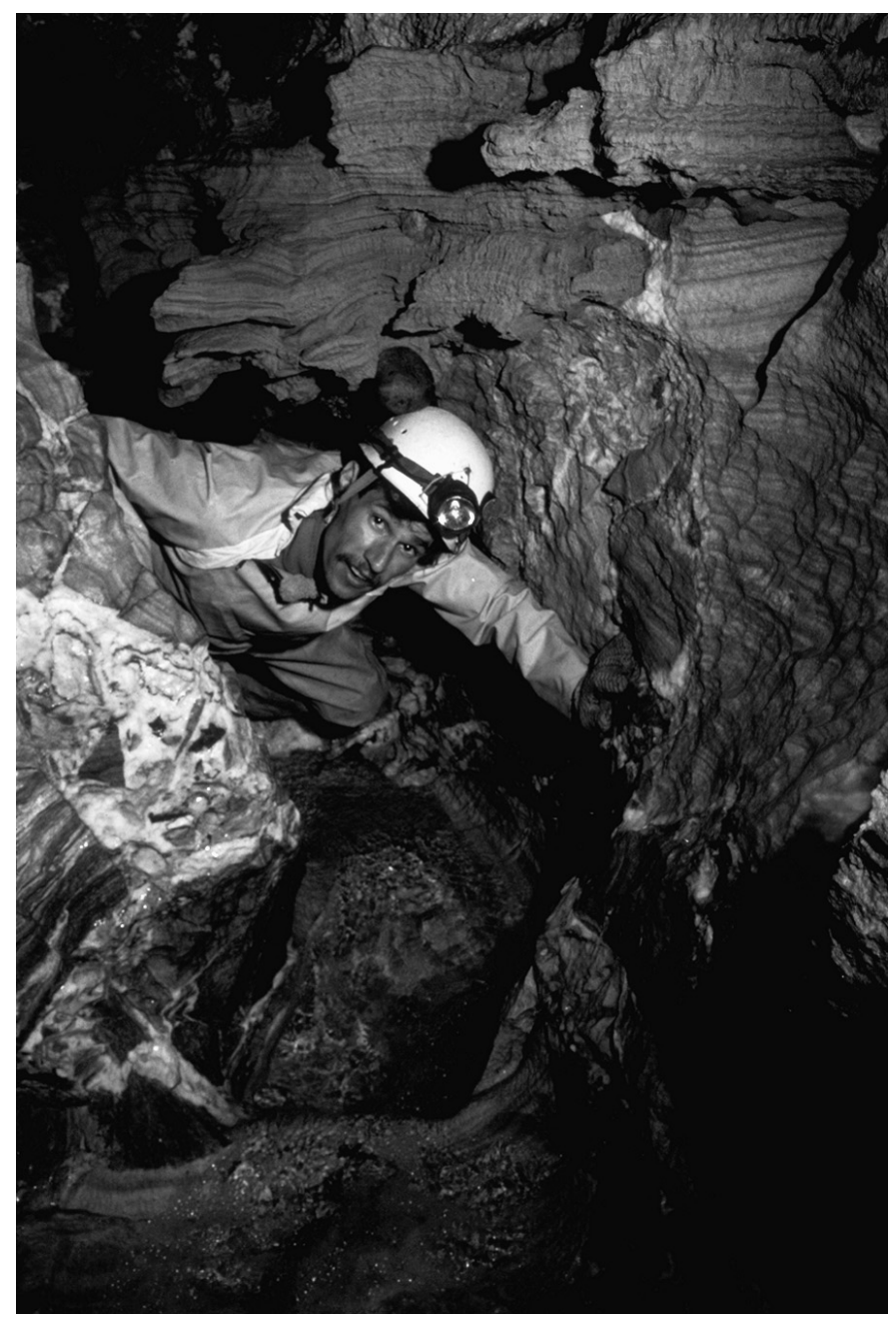

Figure 5. A caver moves through narrow stream passage in Carotene Canyon. This passage is $19 \mathrm{~m}$ tall and averages less than $1 \mathrm{~m}$ wide. Note brecciated marble bedrock and eroded speleothem deposits above the caver's head.

passages, prolific scallops in the cave give evidence for turbulent flow throughout the cave's history that would have entrained sediments, promoting mechanical erosion of marble surfaces.

$\mathrm{HCC}$ is known for its prolific and active speleothems, including large shields, rimstone pools, folia, spar crystals, curtains, and helictites. Many larger pool basins in the cave fill only seasonally, but some generate calcite deposits of up to $0.5 \mathrm{~mm}$ per annum. Cave speleothem deposition constricts and in-fills narrow canyon passages within HCC, creating upstream flooding and trapping sediments by reducing their movement downstream.

As attested by the name, HCC is breezy, with strong convection-generated air currents that reach $48 \mathrm{~km} \mathrm{~h}^{-1}$ at the lower entrance. Cave temperatures vary near the entrances in association with the strong airflow, but constant climatic conditions persist in the central regions of the cave, where temperatures varied less than $0.2{ }^{\circ} \mathrm{C}$ over

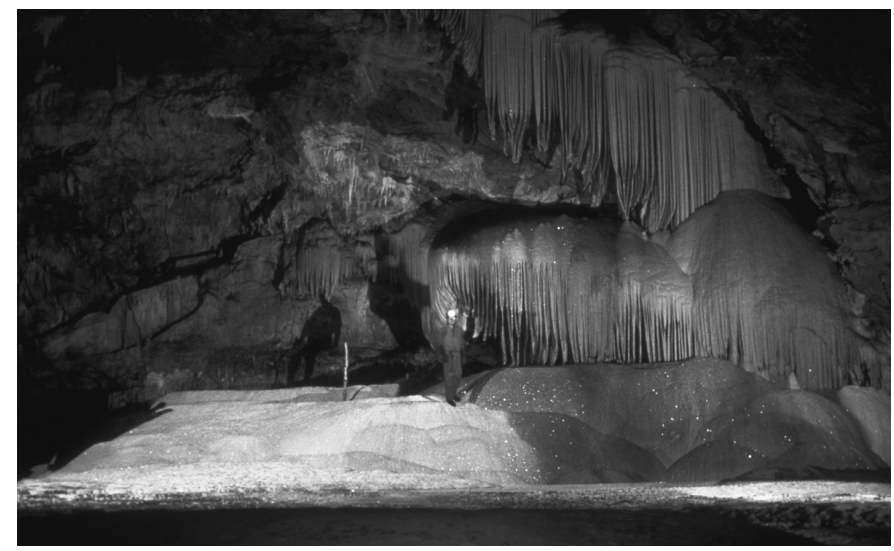

Figure 6. Pumpkin Palace, the largest room in Hurricane Crawl Cave with a maximum width of $38 \mathrm{~m}$.

9 months with a mean of $10.9^{\circ} \mathrm{C}$ in 2009 . The presence of strong air currents apparently allowed soot from at least one wildfire above the cave to be drawn underground, as evidenced by thin black deposits that smear when touched. The deposits cover many areas of speleothems and sediments. In several locations, including the Mizar Rooms, a new growth of white calcite has covered some, but not all, speleothem surfaces, making for starkly contrasting patterns of black and white calcite (Fig. 7).

\section{Methods}

Cave morphology, passage elevations, and basic hydrology were determined through a survey of the cave conducted from 1988 through 1995 using compasses, clinometers, and fiberglass measuring tapes or laser range-finders for high ceilings and tall passages. Data were processed using

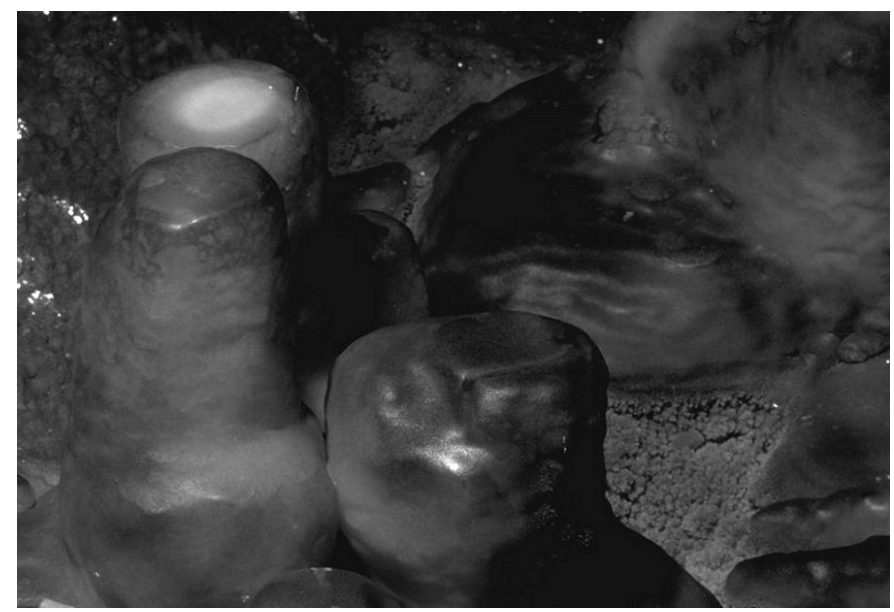

Figure 7. Black stalagmites and flowstone apparently colored by soot and smoke that entered the cave during a surface fire. The single white spot atop of the rear stalagmite attests to recent calcite deposition post-fire.

Journal of Cave and Karst Studies, August 2016 • 75 
Geomorphology and paleohydrology of Hurricane Crawl Cave, Sequoia National Park, California

Table 1. Transect locations.

\begin{tabular}{llccc}
\hline $\begin{array}{c}\text { Transect } \\
\text { Number }\end{array}$ & \multicolumn{1}{c}{ Transect Location } & $\begin{array}{c}\text { Distance from Cave } \\
\text { Terminus, } \mathrm{m}\end{array}$ & $\begin{array}{c}\text { Number of } \\
\text { Measured Sites }\end{array}$ & Transect Height, m \\
\hline 1 & Pleiades and Carotene Canyon & 142 & 7 scallop & 21.6 \\
2 & Star Chamber and Carotene Canyon & 206 & 11 scallop & 24.6 \\
3 & Pumpkin Palace, Sequin Balcony & 367 & 6 cobble & 19.9 \\
4 & Dusted Canyon and Betelgeuse Balcony & 445 & 8 scallop & 19.6 \\
& & & 2 cobble & \\
\hline
\end{tabular}

Compass Software (Fish, 2013) for reduction and display. A surface survey between the cave's two entrances, combined with a traverse through all of the cave's major passages, created a loop with a closure error of less than $1 \%$. This, combined with analysis of additional survey loops, produced a total survey error of less than $2 \%$. The initial mapping effort was supplemented through field checks of draft maps and tying the survey to prominent features in the cave (Despain and Fryer, 2002).

Two years after the cave's 1988 discovery, a sinking stream was noticed in a nearby canyon. This appeared to be an obvious source for Hurricane Crawl Cave's primary stream. We conducted two dye traces in the sinking stream. The first, in 1995, used fluorescein, coconut-husk charcoal receptors, and an eluent solution to complete a qualitative trace using an existing protocol (Smart and Brown, 1973). In 2012, we conducted a second dye trace in the same stream and in two adjacent sinking streams. Results of this trace were presented in Tobin (2013) and confirmed that the sinking stream discovered in 1988 was the only surface stream among those traced that flowed through the cave. However, observations suggest that the discharge differed greatly between the sinking stream's insurgence and the resurgence, implying a larger diffuse source feeding the cave stream. Under baseflow conditions, diffuse recharge sources also predominate in other karst in the North Fork of the Kaweah's watershed and other watersheds in the Kaweah area (Tobin, 2013).

We measured seasonal discharge values from 2010 to 2012 for comparison to paleodischarge, discussed below, using a pygmy meter and established methods (Shelton, 1994). We measured flow in a confined stretch of the main cave stream above Strawberry Falls twice per year, during high flow in June and in during baseflow conditions in October.

Geochronologic data from HCC were published in Stock et al. (2004, 2005a, 2005b). Paleomagnetic orientations of fine-grained sediments throughout the cave consistently indicated deposition during times of normal magnetic polarity. These include fine-grained sediment collected from an upper level passage in the Pleiades area, where an underlying granitic cobble yielded a cosmogenic ${ }^{26} \mathrm{Al} /{ }^{10} \mathrm{Be}$ burial age of $0.93 \pm 0.24 \mathrm{Ma}$. Stock et al. (2005b) concluded that, given the stratigraphic relations in this area, either the fine sediment was deposited during one of the normal chrons prior to $0.93 \mathrm{Ma}$ or the fine sediment was deposited stratigraphically above the coarse sediment by floodwaters entering the passage sometime after the Bruhes-Matuyama magnetochron boundary $0.78 \mathrm{Ma}$. A single cosmogenic burial-age sample was collected from HCC for the 2004 and 2005 papers, as the focus of that work was regional. Samples for the project were collected in caves in the southern and central Sierra Nevada and were processed at UC Santa Cruz and at the Lawrence Livermore National Laboratory's Center for Accelerator Mass Spectrometry.

Asymmetric bedrock scallops on cave surfaces can be used to infer both paleoflow direction and velocity. We use the method defined by Curl (1974) for determining paleoflow. As evidenced by bedrock features, turbulent flow that would entrain significant quantities of sediments, particularly during floods, was significant in the development of cave passages in Hurricane Crawl Cave. However, Curl does not consider kinematic viscosity in his calculations for determine flow velocity in caves from scallops. Thus velocity and discharge values presented here are likely to be over-estimated by this method and should be considered maximum possible values.

We examined 327 scallops at 27 locations and 157 cobbles at 13 locations along four vertical transects (Table 1) in locations chosen for their vertical extent and locations along the length of the cave (Fig. 2 and Fig. 3). We selected scallops for measurement based on their location, elevation, and abundance and the presence of distinct scallop margins needed for measurement. Scallop lengths were measured across their greatest lengths, and the widths were measured normal to the lengths.

Sampling transect 1 begins in Carotene Canyon where the cave stream flows over bedrock and extends $21.6 \mathrm{~m}$ straight up a narrow canyon. The transect ends on the margins of the larger Pleiades passages. Within the Pleiades, copious calcite deposits have covered most bedrock surfaces and sediments. Seven sets of scallops and two of cobbles were measured. Calculated paleodischarges for this and the other transects are given in Tables 2 and 3.

Transect 2 also begins at stream level in Carotene Canyon and extends $19 \mathrm{~m}$ upwards in the canyon, through the 


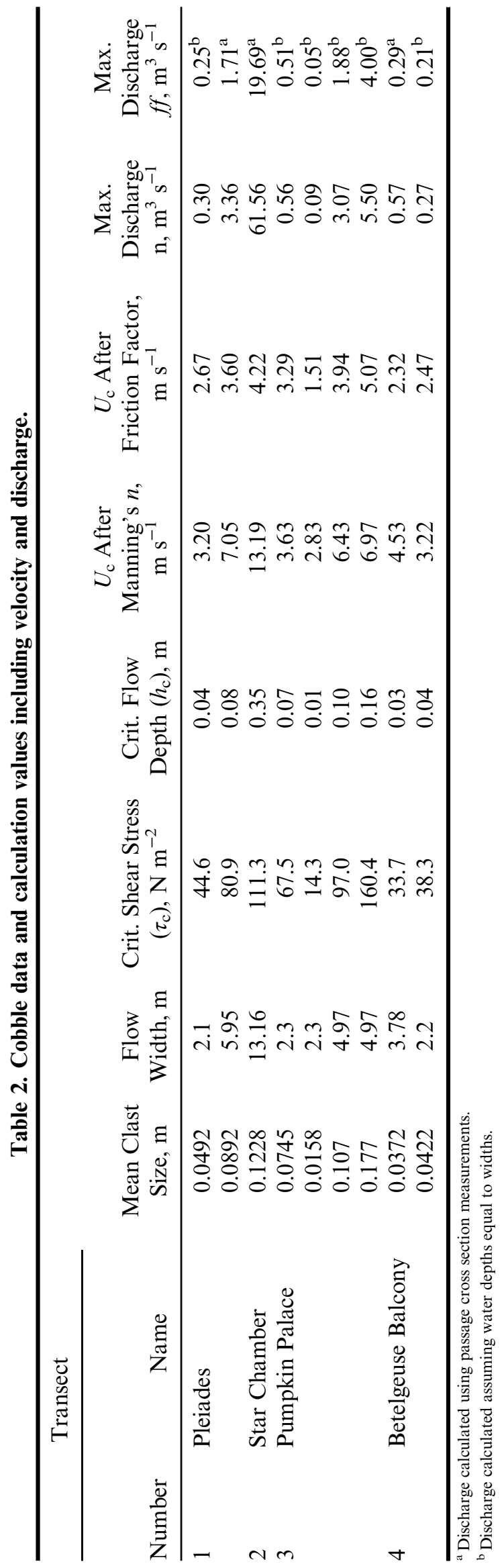

broad and wide Star Chamber level, and upward into another canyon, the highest passage in the cave, for a total height of $24.6 \mathrm{~m}$. We measured 11 sets of scallops and three cobble locations in this transect.

Transect 3 lies in the large room at the center of the cave, Pumpkin Palace, and includes the adjacent ceiling alcove known as Sequin Balcony. No scallops were found in the room, the balcony, or immediately adjacent passages, but six cobble sites were measured. However, cobble locations were few, and we measured them in two different locations that do not constitute a vertical transect. We measured four sets of cobbles in Sequin Balcony and on the climb up to it. The highest is $19.9 \mathrm{~m}$ above the stream and the lowest 17.7. Two sets of cobbles were measured across the room where the entrance passage intersects. These cobbles are $1.5 \mathrm{~m}$ and $1.02 \mathrm{~m}$ above the stream.

Transect 4 is upstream of Pumpkin Palace and starts from the bottom of Dusted Canyon, extending to the upper level in this area known as Betelgeuse Balcony, reached by a roped ascent. We measured two cobble deposits and eight scallop sites along this transect encompassing a total height of $19.6 \mathrm{~m}$.

Passage cross-sectional areas can be difficult to determine. In the well-defined passages of the Star Chamber, the Pleaides, and the Betelgeuse Balcony measurements were made directly for passage width and height, including wall irregularities and variations in floor elevations and ceiling heights. Some passage surfaces are obscured by deposits of sediments and calcite, adding uncertainty to the original cross-sectional area. Tall canyon passages in HCC are essentially ceiling-less. Here we assumed water depth equal to passage width. Collectively these data provide values for paleoflow velocities and discharges that help to illuminate the cave's hydrologic history. The two approaches for determining cross-sectional area, actual measurement or assumed equal height and width, are noted in the last columns in Tables 2 and 3. Discharge values are maximum possible flows since they assume pipe-full conditions, which would only occur during extreme floods, if ever, in larger passages.

Curl demonstrated a relation between mean scallop length, $L$, and the Reynolds number, $\mathrm{Re}_{L}$, for scallops in both parallel-wall and circular conduits. We determined mean scallop lengths for each set of scallop populations and used Curl's predicted relation between the Reynolds number and the ratio of conduit width $D$ to $L$, in parallelwall conduits to determine $\mathrm{Re}_{L}$ values for each site. We then used the relation between $L$ and $\operatorname{Re}_{L}$ to calculate mean flow velocity, $v$, through these conduits using the relation $v=v \operatorname{Re}_{L} / L$, where $v$ is the kinematic viscosity ( $\sim 0.013 \mathrm{~cm}^{2} \mathrm{~s}$ for fresh water at $10{ }^{\circ} \mathrm{C}$; Curl, 1974).

Stream deposited cobbles were found to be in sorted and layered beds with varied sediment sizes ranging from sand to cobbles, to lie in flat-topped beds as opposed to slumped, sloped and angled piles of infill or collapse, to include rock types not found within the cave, predominantly granodiorite, to be consistently rounded on all axes, to be in immediate association with other evidence of fluvial action 
Table 3. Scallop data and calculated values including velocity and discharge.

Transect

\begin{tabular}{|c|c|c|c|c|c|c|c|}
\hline Number & Name & $\begin{array}{c}\text { Mean } \\
\text { Scallop, m }\end{array}$ & $\begin{array}{l}\text { Conduit } \\
\text { Width, m }\end{array}$ & $R e_{L}$ & $\begin{array}{l}\text { Velocity } \\
(v), \mathrm{m}^{3} \mathrm{~s}^{-1}\end{array}$ & $\begin{array}{c}\text { Cross-sectional } \\
\text { Area, } \mathrm{m}^{2}\end{array}$ & $\begin{array}{l}\text { Discharge, } \\
\mathrm{m}^{3} \mathrm{~s}^{-1}\end{array}$ \\
\hline \multirow[t]{7}{*}{1} & \multirow[t]{7}{*}{ Pleaides } & 0.037 & 0.41 & 0.0247 & 0.87 & 0.168 & $0.15^{\mathrm{b}}$ \\
\hline & & 0.042 & 1.4 & 0.0309 & 0.96 & 1.96 & $1.89^{\mathrm{b}}$ \\
\hline & & 0.0245 & 0.41 & 0.0270 & 1.44 & 0.168 & $0.24^{\mathrm{b}}$ \\
\hline & & 0.019 & 0.41 & 0.0285 & 1.96 & 0.168 & $0.33^{\mathrm{b}}$ \\
\hline & & 0.018 & 0.540 & 0.0303 & 2.21 & 0.292 & $0.64^{\mathrm{b}}$ \\
\hline & & 0.0313 & 0.71 & 0.0287 & 1.20 & 0.504 & $0.61^{\mathrm{b}}$ \\
\hline & & 0.0347 & 1.92 & 0.0338 & 1.28 & 3.686 & $4.70^{\mathrm{b}}$ \\
\hline \multirow[t]{11}{*}{2} & \multirow[t]{11}{*}{ Star Chamber } & 0.0283 & 1.37 & 0.0331 & 1.53 & 1.877 & $2.87^{\mathrm{b}}$ \\
\hline & & 0.0422 & 0.5 & 0.0250 & 0.78 & 0.25 & $0.19^{\mathrm{b}}$ \\
\hline & & 0.0355 & 0.69 & 0.0279 & 1.03 & 0.476 & $0.49^{\mathrm{b}}$ \\
\hline & & 0.029 & 2.6 & 0.0366 & 1.65 & 6.76 & $11.16^{\mathrm{a}}$ \\
\hline & & 0.036 & 1.7 & 0.0329 & 1.20 & 2.89 & $3.46^{\mathrm{b}}$ \\
\hline & & 0.0429 & 2.9 & 0.0350 & 1.07 & 8.41 & $8.97^{\mathrm{a}}$ \\
\hline & & 0.0309 & 0.79 & 0.0294 & 1.27 & 0.624 & $0.78^{\mathrm{b}}$ \\
\hline & & 0.025 & 1.8 & 0.0353 & 1.87 & 3.24 & $5.99^{\mathrm{b}}$ \\
\hline & & 0.031 & 0.89 & 0.0301 & 1.27 & 0.792 & $1.01^{\mathrm{b}}$ \\
\hline & & 0.0162 & 1.3 & 0.0359 & 2.91 & 1.69 & $4.91^{\mathrm{b}}$ \\
\hline & & 0.0295 & 1.5 & 0.0333 & 1.48 & 2.25 & $3.337^{\mathrm{b}}$ \\
\hline \multirow[t]{8}{*}{4} & \multirow[t]{8}{*}{ Betelgeuse Balcony } & 0.0301 & 4.72 & 0.0398 & 1.73 & 22.28 & $38.51^{\mathrm{a}}$ \\
\hline & & 0.02 & 1.6 & 0.0359 & 2.35 & 2.56 & $6.02^{\mathrm{b}}$ \\
\hline & & 0.03775 & 0.9 & 0.0290 & 1.03 & 0.81 & $0.81^{\mathrm{b}}$ \\
\hline & & 0.0399 & 1.3 & 0.0308 & 1.01 & 1.69 & $1.71^{\mathrm{b}}$ \\
\hline & & 0.032 & 1.7 & 0.0336 & 1.37 & 2.89 & $3.98^{\mathrm{b}}$ \\
\hline & & 0.022 & 1.2 & 0.0337 & 2.01 & 1.44 & $2.90^{\mathrm{b}}$ \\
\hline & & 0.044 & 1.6 & 0.0314 & 0.93 & 2.56 & $2.39^{\mathrm{b}}$ \\
\hline & & 0.035 & 0.8 & 0.0288 & 1.08 & 0.64 & $0.69^{\mathrm{b}}$ \\
\hline
\end{tabular}

${ }^{a}$ Discharge calculated using passage cross section measurements.

${ }^{\mathrm{b}}$ Discharge calculated assuming water depths equal to widths.

including scallops and eroded bedrock, to be common throughout the cave, and to occur tens to hundreds of meters below ground and far from evidence of collapse or infill from the surface.

Deposits of stream cobbles can be used to determine paleovelocity of cave streams through the critical shear stress required to entrain them in cave-stream flow (e.g., Despain and Stock, 2005). For spherical particles, such as fluvially deposited cobbles, the relationship between critical shear stress, $\tau_{\mathrm{c}}$, and particle size, $D$, is described by the Shields equation $\tau_{\mathrm{c}}=\beta\left(\rho_{\mathrm{p}}-\rho_{\mathrm{f}}\right) g D$, where $\beta$ is the Shields function ( 0.056 for typical gravel beds), $\rho_{\mathrm{p}}$ is the particle density $\left(2700 \mathrm{~kg} \mathrm{~m}^{-3}\right), \rho_{\mathrm{f}}$ is the fluid density $(1000 \mathrm{~kg}$ $\left.\mathrm{m}^{-3}\right), g$ is gravitational acceleration $\left(9.81 \mathrm{~m} \mathrm{~s}^{-2}\right)$, and $D$ is the sediment particle diameter in meters (Shields, 1936). We examined 157 sediment particles at 13 sites. At each site, we measured the population of largest spherical particles' diameters, which best represents the maximum discharge conditions before the basal shear stress of the flow fell below the critical shear stress necessary to transport the particles. We then used $\tau_{\mathrm{c}}$ values to calculate the critical flow depths, $h_{\mathrm{c}}$, required to entrain the particles, using an expression for basal shear stress $\tau_{\mathrm{c}}=\rho_{\mathrm{f}} g h_{\mathrm{c}} S$, where $S$ is the local passage slope (Bagnold, 1966). We determined passage slopes by dividing passage lengths by the change in elevation along the passage length. Lengths and slopes were $82 \mathrm{~m}$ and $3.2 \%$ in the Star Chamber and $400 \mathrm{~m}$ and $10.3 \%$ along the bedrock bottom of Carotene and Dusted canyons, respectively. We determined critical flow velocities, $U_{\mathrm{c}}$, by combining the critical flow depths with two different methods for estimating the flow resistance. The first method uses a friction factor, $f$, which is a function of the Reynolds number and the relative conduit roughness: $U_{\mathrm{c}}=\left(8 g h_{\mathrm{c}}\right.$ $S(f)^{0.5}$, where $f$ is the friction factor, assumed to be 0.05 , a value typical for turbulent flow in most cave conduits (Palmer, 1987). The second method of calculating the critical flow velocity utilizes a flow resistance based on hydraulic radius: $U_{\mathrm{c}}=R_{\mathrm{H}}{ }^{0.66} S^{0.5} / n$, where $R_{\mathrm{H}}$ is the hydraulic radius, determined using passage width and the critical flow depth $h_{\mathrm{c}}$. The variable $n$ is Manning's roughness coefficient $0.32 S^{0.38} h_{\mathrm{c}}{ }^{-0.16}$. We multiplied the critical flow velocities calculated by these two methods (friction factor $f$ and Manning's $n$ ) by passage cross-sectional area to derive maximum paleodischarges. 


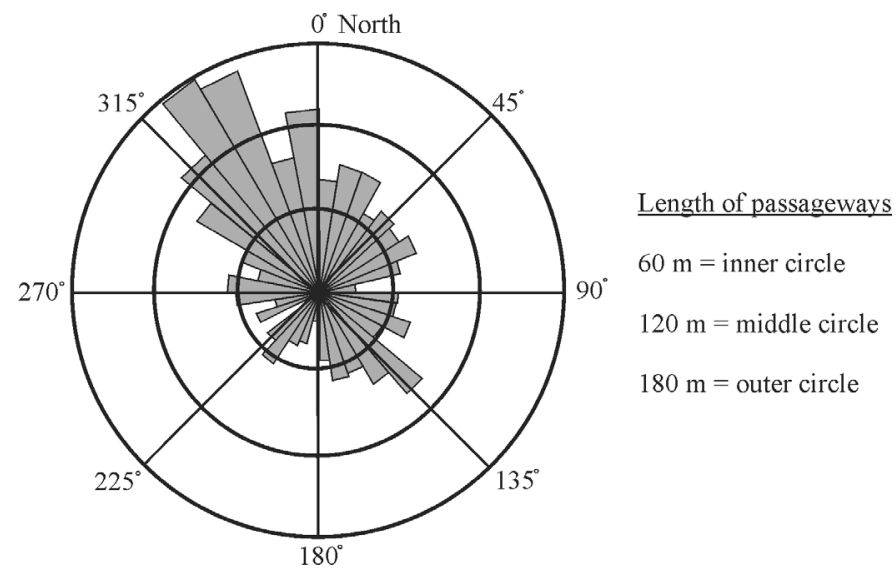

Figure 8. Rose diagram of Hurricane Crawl Cave (Fish, 2013) showing passage orientations as determined by the cave survey.

\section{RESULTS}

HCC has three perennial and several seasonal streams. The primary stream pirated from Windy Canyon is seen in the Mizar Maze at the north end of the cave and downstream from Pumpkin Palace through Carotene Canyon, and it emerges at springs just downstream of the lower cave entrance along the local master stream. A tributary is found in Dusted Canyon, where a very low discharge stream originates from an area of dense secondary deposits near the Mizar Maze passages. The other perennial stream rises from another area of prolific secondary calcite in meandering Schist Canyon that has formed along an irregular schist contact.

Passage orientations reveal strong structural control on cave development. The overall trend of the cave is 330 to 150 degrees on strike across the near vertically bedded marble (Fig. 8). Passage development is also controlled by irregular contacts with schist bodies and significant sub-parallel fracture networks. Some of the length is due to the presence of anastomotic and network mazes (Palmer, 1975; 1991). Calcite-cemented marble breccia is found in lower Carotene Canyon, implying minor faulting and offset on strike in that area of cave development (Fig. 5).

Scalloped narrow canyons, such as at Transect 2 where the passage is 1 to $2 \mathrm{~m}$ wide and $17.5 \mathrm{~m}$ tall, and active streams point to vadose development by free-flowing streams and turbulent flow through at least $40 \%$ of the

Table 4. Overlying upper level and lower-level passage gradients.

\begin{tabular}{lcr}
\hline Cave Passage & Elevation Range, m & Slope \\
\hline Star Chamber, upper level & 2.7 & 1.5 \\
Carotene Canyon, lower level & 7.9 & 10.7 \\
All upper levels & 9.5 & 1.6 \\
All lower levels & 18.0 & 10.3 \\
\hline
\end{tabular}

cave's passages, including the network maze. As determined from the cave survey, the vadose passages have higher gradients compared to other levels (Table 4). Comparatively wide upper level passages with a lower gradient constitute about $10 \%$ of surveyed cave passages and have fewer scallops. Other areas that lack scallops include the anastomotic Mizar Maze and Pumpkin Palace, the large room in the center of HCC.

The first dye trace, in 1995, showed that the water in the largest and longest stream inside HCC, and in the springs adjacent to the cave entrance, originates on the surface at a sinking stream draining a watershed of approximately $1.2 \mathrm{~km}^{2}$. The straight-line distance through the karst from sink to spring is approximately $475 \mathrm{~m}$. Transit time of the dye was less than three days. While the stream can be followed for hundreds of meters inside the cave, it is not possible to approach the sink point or the resurgence underground due to breakdown collapses. The other two perennial streams are likely related to diffuse inputs, as no other surface streams are found in the area or were traced to the cave in the 2012 dye trace.

Cave and surface streams show strong seasonal variation in discharge in the Sierra Nevada in accord with the Mediterranean climate. Thus baseflow and high-flow values are both of interest. Discharge measurements in the main cave stream from 2010 into 2012 ranged from $0.042 \mathrm{~m}^{3} \mathrm{~s}^{-1}$ to $0.007 \mathrm{~m}^{3} \mathrm{~s}^{-1}$ during high flow and $0.004 \mathrm{~m}^{3} \mathrm{~s}^{-1}$ to $0.002 \mathrm{~m}^{3} \mathrm{~s}^{-1}$ during baseflow conditions. The measurements missed the peak discharge of the cave stream during the sampling years.

Conditions during the cave's history limited cave-stream flow during certain periods. Insurgences in the unglaciated karst regions of the southern Sierra Nevada are frequently choked by granitic sediments, restricting and reducing discharge and additional sediment input into the cave systems. Current examples include the insurgences for Hurricane Crawl, Crystal, Lilburn, and other caves. Under these conditions, flow frequently bypasses the cave and continues in surface channels. When insurgence conduits are open, floods with high velocity flow move sediments deeper into cave passages and farther from entrances. Recent large flood events have been documented in park caves, including Wild Child (Despain and Stock, 2005) and Lilburn (Tinsley, et al., 1981; Despain and Stock, 2005) caves. This occurred most prominently on January 2, 1997, after a rain-on-snow event. Flooding occurred in both Lilburn and Wild Child that night, when the Kaweah had a peak flow of $1555 \mathrm{~m}^{3} \mathrm{~s}^{-1}$ in Three Rivers below the park, compared to an average flow of 15 $\mathrm{m}^{3} \mathrm{~s}^{-1}$ from 1959 to 1990 .

Cosmogenic ${ }^{26} \mathrm{~A} 1 /{ }^{10} \mathrm{Be}$ concentrations suggest that the granitic cobble from the Pleiades level of Hurricane Crawl was buried $0.93 \pm 0.24 \mathrm{Ma}$ (Stock et al., 2004; 2005a; 2005b). The vertical distance from this dated stream cobble to the active cave stream at the bottom of narrow Carotene Canyon (Transect 1) is $21.2 \mathrm{~m}$, giving a cave stream downcutting rate of approximately $0.02 \mathrm{~mm} \mathrm{y}^{-1}$. This rate is 
Table 5. Summarized discharge results using results from the friction factor calculation method.

\begin{tabular}{lcccc}
\hline \multicolumn{2}{c}{ Transect } & & & \\
\cline { 1 - 1 } Number & Name & $\begin{array}{c}\text { Maximum, } \\
\mathrm{m}^{3} \mathrm{~s}^{-1}\end{array}$ & $\begin{array}{c}\text { Minimum, } \\
\mathrm{m}^{3} \mathrm{~s}^{-1}\end{array}$ & $\begin{array}{c}\text { Mean, } \\
\mathrm{m}^{3} \mathrm{~s}^{-1}\end{array}$ \\
\hline 1 & Pleaides & 4.7 & 0.15 & 1.17 \\
2 & $\begin{array}{c}\text { Star } \\
\text { Chamber }\end{array}$ & 23.35 & 0.19 & 6.27 \\
& & & & \\
& Pumpkin & 4.0 & 0.05 & 1.61 \\
& Palace & & & \\
& Betelgeuse & 38.5 & 0.21 & 5.75 \\
& Mean & 17.64 & 0.15 & 3.7 \\
\hline
\end{tabular}

similar to stream incision rates in other drainages of the southern Sierra Nevada (Stock et al., 2004; 2005a). The cave extends upward at least $12 \mathrm{~m}$ above the cobble sample location into the highest cave level, another narrow scalloped canyon. Assuming the same rate of cave passage development and down-cutting as lower in Carotene, the upper canyon would have developed over a minimum of $0.52 \mathrm{Ma}$. This would make the minimum potential age for the cave approximately $1.4 \mathrm{Ma}$, which is consistent with other measured cave ages in the southern Sierra Nevada (Stock et al., 2004; 2005a; 2005b).

Scallop orientations show that the present pattern of water flow through the cave persisted throughout the duration of cave development. This observation is corroborated by both ceiling and floor gradients of existing passages and by occasional imbrication of coarse sediments.

Cobbles sizes (Table 2) and scallop lengths (Table 3) indicate moderate to very high paleo-flow velocities. Scallopand cobble-derived velocities vary little by transect or by elevation along the transects. The velocities depend less on passage morphology than the discharge values discussed below. Mean scallop velocity is $1.44 \mathrm{~m} \mathrm{~s}^{-1}$, while cobbles show $3.23 \mathrm{~m} \mathrm{~s}^{-1}$ for the friction-factor velocities in Table 2. The cobble data include a few higher values from the Star Chamber, where calculated values range up to $13.9 \mathrm{~m} \mathrm{~s}^{-1}$ for two large rocks, according to Manning's method. Cobbles document higher flows and likely larger flood events compared to scallops.

Mean high-discharge data are more consistent, at $4.85 \mathrm{~m}^{3} \mathrm{~s}^{-1}$ for cobbles based on the friction-factor formula and $4.18 \mathrm{~m}^{3} \mathrm{~s}^{-1}$ for scallops. The data have a near-normal but positively skewed distribution reflecting a few very high discharge events that are orders of magnitude higher than current discharge values. Values range over four orders of magnitude from $0.05 \mathrm{~m}^{3} \mathrm{~s}^{-1}$ to $66.1 \mathrm{~m}^{3} \mathrm{~s}^{-1}$ for a cobble in the Star Chamber calculated using Manning's $n$. For comparison, modern calculated flood values for the watershed upstream of the cave insurgence produce values of $4.9 \mathrm{~m}^{3} \mathrm{~s}^{-1}$ for 100-year events and $8.27 \mathrm{~m}^{3} \mathrm{~s}^{-1}$ for 500 -year events (USGS, 2015).

Mean discharge varies for the four transects; two results are a magnitude larger (Table 5). These transects include sample locations in the wide, phreatic upper levels, producing much larger discharge values due to much larger crosssectional areas. Mean discharge from the larger passages is $27 \mathrm{~m}^{3} \mathrm{~s}^{-1}$, while in the canyons the mean is $2.47 \mathrm{~m}^{3} \mathrm{~s}^{-1}$. There is little variation in discharge values from each transect and thus there is little variation over elevation and time. Rather discharge values in this study are determined by passage morphology and size. Overall mean paleo-discharge is $3.7 \mathrm{~m}^{3} \mathrm{~s}^{-1}$, far above current average or even high flow for the cave stream. Greater variations in paleodischarge are seen in wider upper level passages that were subject to larger floods, as evidenced by the cobbles measured for this study.

As a first order approximation, overall scallop and cobble measurements imply extremely variable discharges, presumably due to these floods, a common occurrence in steep, mountainous catchments. This is supported by three discharge values in the Betelgeuse and Star Chamber transects that are approximately an order of magnitude larger than the transect means, skewing the transect discharge means to higher values. These values provide evidence for infrequent but very large discharge events in the dissolution and sedimentation of the cave.

\section{Discussion}

The hydrologic history of the cave is dominated by active vadose streams that created the narrow canyon at the cave's highest level and the $20 \mathrm{~m}$ tall current active stream passages of Carotene and Dusted canyons that make up much of the length of the cave. Also of vadose origin is the downstream maze, the Parallel Passages. This is a network of canyon passages developed on parallel beds in the vertically oriented marble. The maze in the downstream end of the cave is near an entrance and in an area subject to surface channel erosion, channel aggradation, and landslides; all of which can encourage the development of parallel conduits and hydrologic piracies when passages are blocked or constricted by sediment or collapse (Palmer, 1975). Headward migration of knickpoints in the steep surface canyon below the cave's spring and lower entrance drove vadose incision as the cave streams eroded downward toward base level.

An important exception to canyons are the scallop-less, wide, and broadly meandering level of the Pleiades, Star Chamber, Sequin Balcony, and Betelgeuse passages. We interpret these passages as forming under phreatic conditions because they exhibit low gradients and morphologies indicating low-velocity turbulent flow (Bogli, 1964). Why the active downcutting of the cave stream paused for thousands of years to create a broad low-gradient cave passage under different hydrologic conditions is unclear. Increased run off, rainfall, or sedimentation rates, the rapid migration of knickpoints through the marble unit (Despain and Stock, 
2005), or local landslides that could bury cave entrances and effectively aggrade streams are all possibilities.

Other areas lacking scallops are the anastomotic Mizar Maze and Pumpkin Palace. Both lie at the junctions of tributary streams, allowing for mixing-zone chemistry to affect and possibly increase passage development (White, 1988; Bogli, 1964). Ceiling and wall surfaces of Pumpkin Palace and Mizar Maze, where they can be directly observed, are eroded bedrock, as opposed to collapses or fractured walls. However, this may reflect only current conditions, and evidence for earlier collapse may have eroded away. Both Pumpkin Palace and Mizar Maze are upstream of narrow canyons with prominent secondary speleothems that constrict cave passages. The active streams have only a small erosional effect on calcite deposition at passage constrictions. Evidence of erosion extends only $0.5 \mathrm{~m}$ above base flow. Both areas also contain voluminous quantities of granitic sediment deposited where stream velocities decreased behind the speleothem constrictions.

Seasonal flooding and storm discharges overwhelm conduits compromised by high sediment loads, which promotes the development of parallel conduits that bypass constrictions and create anastomotic mazes (Palmer, 1975; 1991). In the Mizar Maze, sediments aggraded behind constrictions, allowing the primary cave stream and the stream from Schist Canyon to meander, broadening passages and promoting curvilinear anastomotic maze development under little influence from prominent vertical bedding and joints (Palmer, 1975). In the Parallel Passages maze near the downstream terminus of the cave, fluvial sediments are sparse due to the filtering effects of constrictions earlier in the cave and the limited capacity of the present streams. The lack of sediments allowed multiple vadose piracies of the primary stream to form this network maze on strike, circumventing areas of collapse or infill at the nearby surface. Thus, sediment flux over time has determined passage morphology in the maze passages of HCC.

Pumpkin Palace, the cave's $35 \mathrm{~m}$ diameter central room, is anomalous, lying at the junction of two narrow vadose canyons and a complex of adjacent smaller rooms. The lack of scallops, even though they are prominent in adjacent passages, implies phreatic, low-velocity turbulent flow conditions during at least the last phases of room development. At the downstream end of the room, the stream sumps for a short distance where there are large deposits of secondary calcite in myriad forms. This includes the named formation areas of Pumpkin Palace itself, the north end of the Star Chamber, and the Dreamsicle. The size of the room may be partly due to mixing of the main stream, which rises near the room, with water from the small, perennial Dusted Canyon stream, generating more aggressive water (White, 1988). The presence of horizontal erosion planes etched into the bedrock above the rise of the stream does suggest chemically aggressive water. The downstream calcite restrictions promoted sediment deposition and stream meandering, contributing to the widening of the room. Ceiling breakdown was subsequently buried beneath sediments or removed by dissolution, increasing overall ceiling height.

Rooms in the Mizar Maze developed at passage intersections where frequent flooding and large sediment loads promoted passage bifurcation and stream widening due to meandering. The smaller rooms in the Parallel Passages occur at passage junctions.

Dusted Canyon, upstream of Pumpkin Palace, is approximately as large and deep as Carotene Canyon, but contains only a minor stream that currently deposits calcite along its entire length. It seems unlikely that the present low flow eroded this large, tall passage. The primary cave stream is seen both up and downstream of this passage, and the canyon likely contained the main flow for most of the cave's history. It was then pirated to lower, unexplored conduits within the last few tens of thousands of years, as judged by the volume of calcite deposits and the current stream and passage elevations.

There is evidence of hydrologic quiescence in cave passages that likely occurred when the primary water flow was diverted to parallel routes or the surface instead of sinking into the cave. This includes remnant bodies of secondary calcite in the phreatic Star Chamber level, where numerous rimstone dams up to $0.75 \mathrm{~m}$ tall are neatly bifurcated above narrow Carotene Canyon below. Calcite deposits are also prominent in Carotene Canyon approximately $1 \mathrm{~m}$ above the primary stream (Fig. 5) and within the modern stream, where speleothems are being actively eroded.

Scallops in canyons document little variation in discharge or velocity through elevation, and thus time, suggesting that the magnitude of scallop-forming flood events has not changed through time. This finding is in general accord with those of Despain and Stock (2005) from Crystal Cave, and also those of Lauritzen et al. $(1983 ; 1985)$, who found that modern scallops in Norwegian caves preserved flood discharges three times larger than mean annual discharges.

Even though our methods produce maximum values for paleo-discharge, current high flow measurements three to five orders of magnitude lower than paleo-discharge calculations warrant discussion. Paleo-flow calculations are reasonable under the circumstances of the development of this cave in this environment. Clearly, clasts and the scallop measurements represent very large flood events. Past greater discharges likely reflect different climatic conditions; the present warm and dry Holocene climate of the Sierra Nevada differs markedly from the cooler, wetter climates of glacial times that dominated most of the past $\sim 2 \mathrm{Myr}$ (e.g., Benson and Thompson, 1987; Hostetler and Clark, 1997; Bartlein et al., 1998; Clark et al., 2003). Paleo-flows of similar magnitude are documented in Crystal Cave by both scallops and cobbles in three locations (Ensantina Passage, Entrance Passage, and Phosphorescent Room) and in HCC by both scallops and cobbles in the Star Chamber and Betelgeuse Balcony. Sediments in abandoned passages derive from the final fluvial inundation at that elevation 

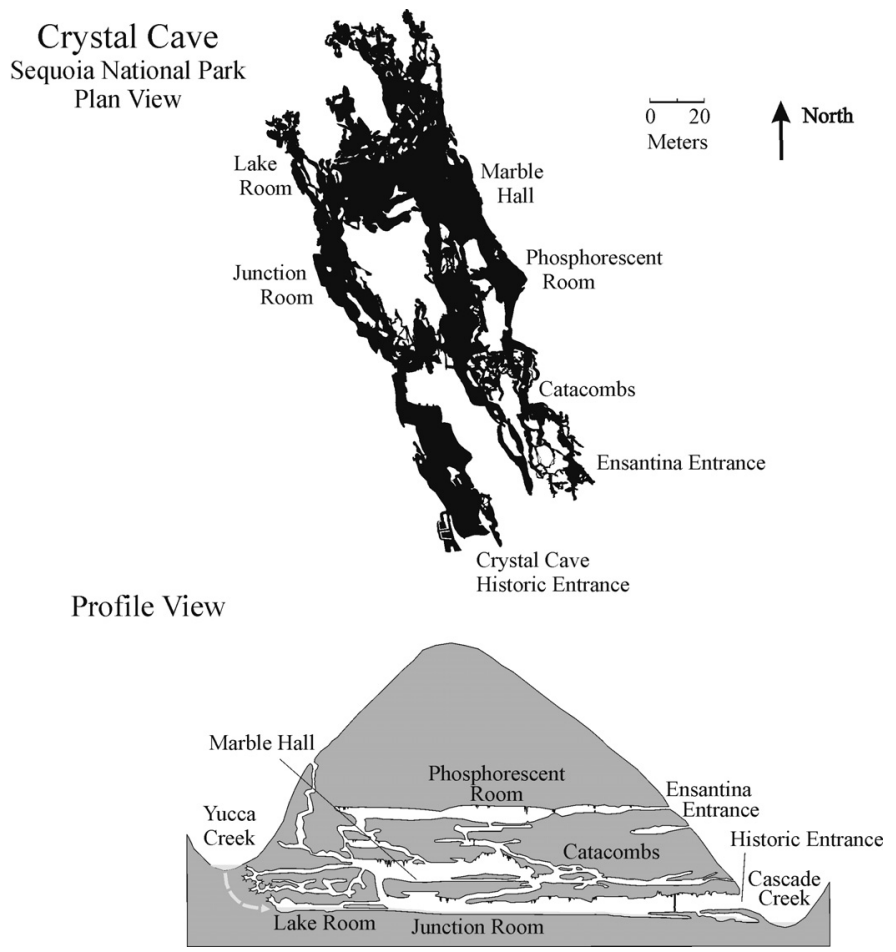

Figure 9. Plan and profile maps of Crystal Cave for comparison to Hurricane Crawl.

and so are likely to be produced by very large flood events that could carry large clasts. While paleo conduits and cave entrances of the size needed to transport such a flood event are not common in the southern Sierra, they do exist at caves such as Alto, Lilburn, and Panorama. Passages at the same elevation in maze complexes in Crystal, Lilburn, and White Chief caves have the collective capacity for floods of the size documented in HCC.

A western system parallel to the known cave passage is inferred from sink and rise points for the primary cave stream on the western margin of known cave passages upstream of Pumpkin Palace, a stream bifurcation to the west in Carotene Canyon below Pumpkin Palace, and the apparent continuation of a calcite-choked passage north from the Pleiades and west of known passages.

\section{Comparison to Crystal Cave}

The basin of the North Fork of the Kaweah contains a number of large cave systems, including the longest in the state, Lilburn Cave (Tinsley, et al., 1981; Bosted, et al, 2003), as well as HCC, Crystal Cave, and many others. HCC and Crystal Cave are formed in vertically bedded host rock and are similar in length, depth, and age (Despain and Stock, 2005). However, they display different geomorphic features. Most of Crystal Cave is composed of anastomotic mazes with a few larger rooms, many passage junctions, and several distinct levels (Fig. 9). Crystal has no network mazes. Only a few canyons occur, and these are generally short $(<30 \mathrm{~m})$ and steep $\left(12^{\circ}\right.$ to $\left.25^{\circ}\right)$ and connect multiple low-gradient horizontal levels.

Both caves have numerous steep vadose passages developed when knickpoints migrated past downstream cave entrances, lowering the local base level and causing erosion and stream down-cutting inside the caves. Horizontal passages developed at several levels within Crystal Cave, while HCC contains one. These low-gradient passages would have developed once the cave stream had reached base level, before the next knickpoint migrated past. The smaller stream in Hurricane Crawl eroded to base level one time, while this happened at least four times in Crystal Cave (Despain and Stock, 2005).

Crystal Cave has copious granitic sediments with particle sizes that vary from large cobbles to clay. Sediments are seen on nearly all flat surfaces, including wall pockets, ledges, shelves, collapsed rocks, and ceiling and wall notches throughout the cave. Recharge conditions allowed large scale inundation by fluvial sediments throughout much of the cave's history. Crystal drains a basin $75 \%$ larger than HCC and contains a larger stream that was likely even larger in the past. Both caves contain clasts and scallops that provide evidence for paleo-flows orders of magnitude larger than current discharges (Despain and Stock, 2005). Paleo-discharge and velocity data from both caves are similar in their range and mean (Table 6). Discharge values for both caves have a larger range than velocity, reflecting variations in conduit size and morphology. Both caves show paleo-discharge values from two to

Table 6. Comparison of Crystal and Hurricane Crawl paleo-velocity values, paleo-discharge values and means. Data were derived using the friction factor method.

\begin{tabular}{|c|c|c|c|c|c|c|c|}
\hline \multirow[b]{2}{*}{ Cave } & \multirow[b]{2}{*}{ Method } & \multicolumn{3}{|c|}{ Velocity $(v), \mathrm{m}^{3} \mathrm{~s}^{-1}$} & \multicolumn{3}{|c|}{ Discharge, $\mathrm{m}^{3} \mathrm{~s}^{-1}$} \\
\hline & & Min. & Max. & Mean & Min. & Max. & Mean \\
\hline \multirow[t]{3}{*}{ Crystal } & Scallops & 0.051 & 0.957 & 0.407 & 0.12 & 15.19 & 4.17 \\
\hline & Cobbles & 0.85 & 5.32 & 2.65 & 0.01 & 39.06 & 8.36 \\
\hline & Mean & 0.45 & 3.14 & 1.53 & 0.065 & 27.13 & 6.27 \\
\hline \multirow[t]{3}{*}{ Hurricane } & Scallops & 0.78 & 2.91 & 1.44 & 0.15 & 38.51 & 4.18 \\
\hline & Cobbles & 1.51 & 4.57 & 3.32 & 0.05 & 23.35 & 4.87 \\
\hline & Mean & 1.15 & 3.74 & 2.38 & 0.1 & 30.93 & 4.53 \\
\hline
\end{tabular}


five orders of magnitude above current discharge. Thus scallops and cobble in both caves reflect similar conditions for deposition of sediments and the formation of bedrock scallops-big floods.

Crystal Cave, while longer in surveyed passage length, developed as a shorter hydrologic system. The current transit of the cave stream through traversable cave passages is 225 $\mathrm{m}$, while in HCC it is $475 \mathrm{~m}$. More of Crystal is closer to its hydrologic input and more prone to seasonal flooding, a return to phreatic and paragenetic conditions, and large sediment loads and inundation that encourage widening of passages by meandering streams and parallel passage development as anastomotic mazes (Farrant and Smart, 2011; Palmer 1975; 1991). The HCC stream has a gradient of $10.3^{\circ}$ and the Crystal Cave stream passage is $1.3^{\circ}$. The higher gradient has encouraged active stream downcutting and the development of vadose canyons continually throughout hundreds of thousands of years in HCC. The canyons contain almost no sediment storage capacity and are easily constricted and even completely blocked by calcite speleothems, which can form rapidly in HCC. Canyon calcite constrictions and areas of collapse reduce the throughput of sediment and starve downstream flows of sediment, further encouraging canyon development and more downcutting, provided base level has not been reached, in a positive feedback.

To summarize, HCC contains a wide variety of geomorphic forms and features developed over a minimum of 1.4 Ma. And although these features vary, they are well explained and understood by current theories of cave development, including the influences of hydrology, porosity, gradient, knickpoint migration, passage constrictions, and in particular, sediments. Flow conditions for scallop development agree with the results of other researchers (Lauritzen et al. 1983, 1985), and the cave's age correlates well with the age of other caves in the area (Despain and Stock, 2005). The varied morphologies of Hurricane Crawl and Crystal caves likely reflect different throughput capacities and budgets for sediment, but otherwise the caves share parallel geomorphic histories.

\section{ACKNOWLEDGEMENTS}

We wish to thank the many members of the National Speleological Society, Western Region, and the Cave Research Foundation, SEKI Operations Area, for volunteering their time to work on surveys, data collection, and photography in Hurricane Crawl and Crystal Caves. This paper would not have been possible without you. Photo in Figure 5 courtesy of Dick Laforge and photos in Figures 6 and 7 courtesy of Dave Bunnell.

\section{REFERENCES}

Abu-Jaber, N., Hess, J.W., and Howcroft, W., 2001, Chemical erosion of the Lilburn Cave System, Kings Canyon National Park, California: Ground Water, v. 39, p. 223-229. doi:10.1111/j.1745-6584.2001. tb02303.x.
Bagnold, R.A., 1966, An approach to the sediment transport problem from general physics: U.S. Department of the Interior, U.S. Geological Survey Professional Paper 422-I, $37 \mathrm{p}$.

Bartlein, P.J., Anderson, P.M., Anderson, K.H., Edwards, M.E., Mock, C.J., Thompson, R.S., Webb, R.S., Webb III, T., and Whitlock, C., 1998, Paleoclimate simulations for North America for the past 21,000 years: features of the simulated climate and comparisons with paleoenvironmental data: Quaternary Science Reviews, v. 17, p. 549-585. doi:10.1016/ S0277-3791(98)00012-2.

Bateman, P.C., and Clark, L.C., 1974, Stratigraphic and structural setting of the Sierra Nevada batholith, California: Pacific Geology, v. 8, p. 79-89.

Benson, L.V., and Thompson, R.S., 1987, The physical record of lakes in the Great Basin, in Ruddiman, W.F., and Wright, H.E., Jr., eds., North America and Adjacent Oceans during the Last Deglaciation: Boulder, Geological Society of America, Geology of North American series K-3, p. 241-259. doi:10.1130/DNAG-GNA-K3.241.

Bogli, Alfred, 1964, Corrosion par mélange des eaux: International Journal of Speleology, v.1, p. 61-70.

Bosted, P., Hacker, B., Despain, J., and Tinsley, J., 2003, Lilburn Cave Atlas, Tulare County, California: Cave Research Foundation, $90 \mathrm{p}$.

Clark, P.U., Weaver, A.J., and Mirovica, J.X., 2003, Ice sheet forcing of abrupt climate change: Lessons from the last deglaciation: Geophysical Research Abstracts, v. 5, \#8091.

Curl, R.L., 1974, Deducing flow velocity in cave conduits from scallops: NSS Bulletin, v. 36, no. 2, p. 1-5.

Despain, J., 1999, A summer of discovery in Hurricane Crawl Cave: NSS News, v. 57, p. 170-173.

Despain, J., and Fryer, S., 2002, Hurricane Crawl Cave: A GIS-based cave management plan analysis and review: Journal of Cave and Karst Studies, v. 64, p. 71-76.

Despain, J.D., and Stock, G.M., 2005, Geomorphic history of Crystal Cave, Southern Sierra Nevada, California: Journal of Cave and Karst Studies, v. 67, p. 92-102.

Farrant, A.R., and Smart, P.L., 2011, Role of sediment in speleogenesis; sedimentation and paragenesis: Geomorphology, v. 134, p. 79-93. doi:10.1016/j.geomorph.2011.06.006.

Fish, L., 2013, Compass Caving Mapping Software Package by Fountain Computer: http://fountainware.com/compass/.

Hostetler, S.W., and Clark, P.U., 1997, Climatic controls of western U.S. glaciers at the last glacial maximum: Quaternary Science Reviews, v. 16. p. 505-511. doi:10.1016/S0277-3791(96)00116-3.

Lauritzen, S.-E., Ive, A., and Wilkinson, B., 1983, Mean annual runoff and the scallop flow regime in a subarctic environment: Preliminary Results from Svartisen, North Norway: Cave Science: The Transactions of the British Cave Research Association, v. 10, p. 97-102.

Lauritzen, S.-E., Abbott, J., Arnesen, R., Crossley, G., Grepperud, D., Ive, A, and Johnson, S., 1985, Morphology and hydraulics of an active phreatic conduit: Cave Science: The Transactions of the British Cave Research Association, v. 12, p. 139-146.

Nokleberg, W.J., 1983, Wallrocks of the Central Sierra Nevada Batholith, California: a Collage of Accreted Tectono-Stratigraphic Terranes: U.S. Department of the Interior, Geological Survey Professional Paper $1255,28 \mathrm{p}$.

Palmer, A.N., 1975, The origin of maze caves: NSS Bulletin, v. 37, p. 56-76.

Palmer, A.N., 1987, Cave levels and their interpretation: NSS Bulletin, v. 49 , p. $50-66$.

Palmer, A.N., 1991, Origin and morphology of limestone caves, Geological Society of America Bulletin, v 103, p. 1-21. doi:10.1130/0016-606 (1991) $103<0001$ : OAMOLC $>2.3 . \mathrm{CO} ; 2$.

Saleeby, J.B., Goodin S.E., Sharp, W.D., and Busby, C.J., 1978, Early Mesozoic paleotectonic-paleogeographic reconstruction of the southern Sierra Nevada region, in Howell, D.G. and McDougal, K.A. eds., Mesozoic Paleogeography of the Western United States: Los Angeles, Society of Economic Paleontologists and Mineralogists, Pacific Section, Pacific Coast Paleogeography Symposium 2, p. 311-336.

Sasowsky, I.D., and White, W.B., 1994, The role of stress release fracturing in the development of cavernous porosity in carbonate aquifers: Water Resources Research, v. 30, p. 3523-3530. doi:10.1029/ 94WR01727.

Shelton, L.R., 1994, Field Guide for Collecting and Processing StreamWater Samples for the National Water-Quality Assessment Program: 
U.S. Department of the Interior, Geological Survey Open-File Report 94-455, $50 \mathrm{p}$.

Shields, A., 1936, Application of similarity mechanics and turbulence research to bedload movement: Pasadena, California Institute of Technology, Hydrodynamics Laboratory publication 167, 44 p. (translation by Ott, W.P., and van Uchelen, J.C., of Anwendung der Ähnlichkeitsmechanik und der Turbulenzforschung auf die Geschiebebewegung: Mitteilungen der Preußischen Versuchsanstalt für Wasserbau und Schiffbau, v. 26.)

Sisson, T.W. and Moore, J.G., 1994, Geologic map of the Giant Forest quadrangle, Tulare County, California: U.S. Geological Survey geologic quadrangle 1751, 1 sheet, scale 1:62,500.

Smart, P.L., and Brown, M.C., 1973, The use of activated carbon for the detection of the tracer dye Rhodamine WT: Proceedings of the Sixth International Speleological Congress, v. 4, p. 285-292.

Stock, G., 1999, Discovery of the Pleiades: NSS News, v. 57, p. 175-180.

Stock, G.M., Anderson, R.S., and Finkel, R.C., 2004, Pace of landscape evolution in the Sierra Nevada, California, revealed by cosmogenic dating of cave sediments: Geology, v. 32, p. 193-196. doi:10.1130/G20197.1.

Stock, G.M., Anderson, R.S., and Finkel, R.C., 2005a, Rates of erosion and topographic evolution of the Sierra Nevada, California, inferred from cosmogenic ${ }^{26} \mathrm{Al}$ and ${ }^{10} \mathrm{Be}$ concentrations: Earth Surface Processes and Landforms, v. 30, p. 985-1006. doi:10.1002/esp.1258.

Stock, G.M., Granger, D.E., Sasowsky, I.D., Anderson, R.S., and Finkel, R.C., 2005b, Comparison of U-Th, paleomagnetism, and cosmogenic burial methods for dating caves: Implications for landscape evolution studies: Earth and Planetary Science Letters, v. 236, p. 388-403. doi:10.1016/j.epsl.2005.04.024.

Tinsley, J.C., DesMarais, D.J., McCoy, G., Rogers, B.W., and Ulfeldt, S.R., 1981, Lilburn Cave's contribution to the natural history of Sequoia and Kings Canyon National Parks, California, USA, in Beck, B.F., ed., Proceedings of the Eighth International Congress of Speleology, volume 1, p. 287-290.

Tobin, B.W., and Schwartz, B.F., 2012, Quantifying concentrated and diffuse recharge in two marble karst aquifers: Big Spring and Tufa Spring, Sequoia and Kings Canyon National Parks, California, USA: Journal of Cave and Karst Studies v. 74, p. 186-196. doi:10.4311/2011 JCKS0210.

Tobin, B.W., 2013, Contributions of karst groundwater to water quality and quantity in a mountain river basin: the Kaweah River, Sequoia and Kings Canyon National Parks, California [PhD dissertation], San Marcos, Texas State University, $182 \mathrm{p}$.

USGS, 2015, USGS California StreamStats: United States Geological Survey, http://streamstatsags.cr.usgs.gov/ca_ss/default.aspx?stabbr $=$ ca\&dt $=$ 1428119007693 [accessed March 19, 2015].

Urzendowski, Linda, 1993, Spectral analysis of the flow behavior of Big Spring, Kings Canyon National Park, California [MS thesis], Las Vegas, University of Nevada, $122 \mathrm{p}$.

White, W.B., 1988, Geomorphology and Hydrology of Karst Terrains: New York, Oxford University Press, 464 p. 